\title{
Interpretation of Proverbs as Moral Messages and Character-Building Motivation: Batak Toba Marriage Customs in Indonesia
}

\author{
Jerry Wilson S.S $\mathbf{1}$, M. Hum
}

\begin{abstract}
In Batak Toba culture, proverbs are widely used in every ceremony. In Batak culture, there are many events, such as birth, baptism, entering a new house, weddings and funerals, which are commonly marked with traditional ceremonies. The use of proverbs in Batak ceremonies not only functions as the transmission of culture but the proverbs also have a meaning and a positive message, the purpose of which is to motivate. Proverbs in Batak Toba ceremonies are like prayers and positive wishes. To understand the meaning and interpretation of a sentence, accurate language analysis is needed, without separating the understanding of the meaning and the interpretation. The knowledge of meaning and translation can be acquired by understanding the science of semantics. Semantics studies the meaning and interpretation literally and figuratively. At a Batak wedding, it is found that the interpretation of the proverbs used is appropriated to the studies of semantics and translation, the purpose of which is to: 1 . Affirm that the marriage cannot be separated by humans. 2. That a marriage is recognised by many people so it is worthy to keep marriage integrity. 3. To build a worthy family by praying and expecting to acquire a good family physically and spiritually. Thus explanation about Batak Toba Proverbs in this analysis.
\end{abstract}

Keywords: Semantics, Translation Theory, Interpretation, Batak Toba, Wedding Culture and Proverb Analysis

\section{Introduction}

Language functions as a tool of communicationin daily life between individuals, groups of people and a nation to communicate, to interact, to change opinions, to convey thoughts, feelings, information, motivate and negotiate in economic, social and cultural activities. This statement is attributed to Sapir (1949: 8), who stated that language is human, not instinctive, in conveying ideas, feelings, emotions and wishes by using speech organs, which produce meaningful sounds. In other words, through language, human thoughts and wishes are conveyed by speech organs. Bloomfield (1933: 42) also stated that language speakers are groups of people that interact using words. All of the above statements refer to human activities, which create intense and continuing relationships for the economy, politics and culture in civil society.

Language as a tool of communication can be defined as a study of ideas in human interactions and contexts in actual social environments, which produce human relationships known as human mind process. In brief, communication is important for human relationships in communities. Steven (1950) states that communication is stimulation for a response, and that word consist of messages, which need to be understood and implemented. The message is suggestive and can motivate people to respond to it.

The language scope is widely developed for a study and analysis. For that reason, language is principally complex because it has research and development study.

That a language characteristic is conventional in which is able to make people extend their work and activities widely according to their needs. It is known that during traditional activities, such as weddings, funerals and religious ceremonies, meaningful wise words, phrases and proverbs can be understood and implemented by groups of people. These conventional language characteristics are accepted not only for social activities but also in professional situations in work areas, such as tourism, culture, education, health, services and many others, literally as well as orally.

Because the character of language is conventional, the result is that a language continually develops in accordance with general situations, which change continuously over time. In this case people have to adapt to the language development. For instance, in a traditional Batak Toba wedding ceremony in North Sumatra the word 'parsuhian' means the giving of an amount of money by the bride's family, for a social group or a civil organization in the place where the bridegroom's family comes from. Certainly, the terminology of the word 'parsuhian' is the result of community agreement. In this way language is developed continuously according to the current situations in that community.

Sapir Whorf has two opinions relating to human language and human culture, known as the Safir Whorf hypothesis. The First Opinion is that language affects the view of social life and its way of thinking. In other words, language affects the way humans see and respond to their environment. This opinion applies to languages in European countries that have caused the changes in verbs at different times. The Second Opinion is that culture and society affect the language to bear a concept that language is a reflection of the language community of the speaker. It shows that language is a tool of cultural transmission, in which by language one can absorb science and technology, develop experience and character, as well as tradition, which is developed where the native speakers live. This is referred to as Language Cultural Function, which is closely related to social science and refers to human attitudes and habits.

The limitations of culture have been greatly discussed. That language is part of culture and evenly said as a dominant factor of culture must have been understood. Human discussion, survival and progress need communication. Many communication examples need to be accurately analyzed. In this relationship language plays an important role in human communication.

\section{Volume 6 Issue 12, December 2017}




\section{International Journal of Science and Research (IJSR) \\ ISSN (Online): 2319-7064}

Index Copernicus Value (2016): 79.57 | Impact Factor (2015): 6.391

The culture of a society is closely related to the language, which is applied by humans to themselves. There is one opinion, which states that language is intertwined and exposed to the pattern of behavioral, inanimate, ideas (belief and knowledge) as well as sentiment (attitudes and norms) in a society. The fact is in accordance with the opinion, which states that language is a relation between individual and socio-cultural values.

The close relationship between language and culture can be reflected in words applied by a community of language speakers in a kinship system. It means that through language, kinship relations in a society can be analyzed. Kinship relations are assigned by a single word that shows a relationship, for example son, daughter, brother, sister, mother, father, etc. In Batak culture, there are many complex and detailed kinships named by terms, such as anak, boru, bere, ibabere, tulang, inang, uda, tua, bou, lae, appara, etc, in which all kinship terms are complete and denote a certain person accurately. This proves a casual relationship between lexicons applied to a particular community's language and culture.

When discussing language, of course there are relationships among the discourse, terminology, construction, meaning, interpretation, syntax, case, text and other aspects of language, whose role is to convey information. Next the writer will also analyze the definition of language related to information that is meaningful to the hearer. Some people will interpret that communication is related to the application of some words, which are conveyed directly.

Language as a branch of science has many interesting aspects to study and to analyze. Language has the potential to convince people through persuasion and innovation by using good and interesting verbs. Language in communication plays an important role in economy, politics, business, education, arts and culture, which make it worth analyzing. Limiting the research to the interpretation of proverbs is to identify the moral message.

Therefore, language has huge and wide reaching benefits for human activities in daily life, which are described in oral and written language. In conveying the information, the form of the words and meaningful sentences of applied language can be analyzed and discussed. Because the conveying of language has elements, which form the sentence, the language can be easily and clearly understood. The information conveyed is surely interesting. In this case the role of language is to create sentences to be more interesting for people.

\section{Batak Toba Culture}

TheBatak Toba ethnic group is situated around Lake Toba and Samosir Island in the Province of North Sumatra, on the island of Sumatra in Indonesia. It is one of Indonesia's largest ethnic groups. The language is Batak with an alphabetical language script. (See http://www.omniglot.com/writing/batak.htm.)

Horas is a Batak Toba greeting, which is used when Batak people meet and part from each other.
It is important for the Batak to have a son, because it is the son who worships the forefathers. A childless woman could hardly show herself in public. The women have been, and still are, the hardest workers amongst the Bataks.

The clan is used by all Batak Toba people and plays a very important role in their lives. For the Batak Toba their clan is of extra importance, as a person cannot marry within his/her clan. In the old days offenders against that rule were sentenced to death. Between and within clans there are special relationships, and special terminology for the relationships in a family, called Dalihan $\mathrm{Na}$ Tolu. The concept of this terminology contains three important relationships, which are hulahula, boru and dongantubu. Hulahula is the relationship of a man to the clan of his wife. Any member of that clan is considered to be an older brother and respect must be shown and given. Boru is the relationship of a man to the clan that his sister marries into. Members of that clan must show respect to the husband's clan. DonganTubu is the relationship between members of the same clan. When a man gets married his family pays for the bride, who then becomes a member of her husband's clan. A village (huta) is normally represented by three clans (marga). Through marriage one clan can achieve all three relationships with other clans. Only the male line is counted.

In Batak culture Gondangmusic is only used in traditional ceremonies. It is played for traditional dancing. A full orchestra consists of musical instruments, such as drums, clarinets, gongs, percussion and bamboo xylophones with 5 or 7 bars. Gondang music is used extensively in traditional ceremonies, such as weddings and funerals. The dance of the Batak Toba is called tor-tor and the gondang music which accompanies the tor-tor includes: GondangMulamula, GondangSahatamangaliat, GondangsiboruandGondangsidoli. Gondangmarsiolopan,

A Batak cannot be without his/her ulos, which is the Batak symbol in Indonesia. An ulos is a hand-woven cloth of indigo blue, combined with red and white. Karo people prefer an ulos with more somber colors and more of the blue. Angkola people have an ulos with beads woven in and brighter colors. Ulos always play an important role in ritual and ceremony, and during many ceremonies, ulos are laid over the shoulders of people, for example a couple who are getting married.

The Batak have been described as animists, or parbegu, before the arrival of Christians and Muslims. The Batak religion was a totally integrated part of their culture but it was in the interests of the newly arrived religions to dismiss the older beliefs as primitive.

One thing that must be known about Batak customs is in the party they have before a ceremony. Batak people always begin a traditional event by having a meal beforehand. The party organizers and host serve big meals to their guests, the purpose of which is to get pasu-pasu (blessings) and to respect their guests. They always serve rice and meat that can be beef or pork. And they also serve jambar, (a piece of meat presented to guests), which is already arranged and divided according to the status of the guests, such as: boru

\section{Volume 6 Issue 12, December 2017 www.ijsr.net




\section{International Journal of Science and Research (IJSR) \\ ISSN (Online): 2319-7064}

Index Copernicus Value (2016): 79.57 | Impact Factor (2015): 6.391

(the women's party, of wives) and paranak(the men's party of husband's), tulang(uncles), tulangrorobot and bona tulang(father's and mother's uncles of the host), suhut(the host), parsahutaon (the community helpers during the party).

The Batak also have proverbs derived from their ancestors' wisdom and intelligence. Great use of proverbs is made during a traditional party. A Batak proverb usually contains a sentence of two lines. The first line is always related to nature, life and the Batak region, and refers to plants and trees, farming, animals etc. The second line is the aim of the proverb, which could be a message of wisdom, positive expectations or a prayer. The writing of proverbs usually applies the characteristics of nature or an animal or object as an analogy of motivational and educational interest for humans. Proverbs are written in a very special way, using poetic and enigmatic words so that the central meaning cannot be easily understood and interpreted. A proverb acts as law if it is applied at appropriate events and times. One example of a Batak proverb is:

Molometmetbinanga, nametmet do dengke

Mologodangbinanga, godangdengke

If the river is small, the fish is small

If the river is big, the fish is big.

This proverb means the sentence given to a guilty man must be appropriate to his crime.

Another example is:

Jolotiniktipsanggarlahobahenonhuruhuruan

Jolosinukkunmargaasabinotopartuturan

Cut the twigs before making a birdcage.

Ask the clan before forming a relationship.

This proverb is addressed to young people so that they understand they must be polite and respect their clan when forming relationships with people.

Many kinds of proverbs have been created, quoted and applied by Batak people in accordance with their needs and the situation. The proverbs used for pamasumasuanparbagason are different from the proverbs for manulangiand other events.

\section{Batak Toba Marriage}

The well-maintained culture of the people of Batak Toba, is evident in the implementation of their traditional events, such as maresekesek to give thanks for a newborn baby; at the mamongotijabu is a ceremony before entering and living in a newly built house; for mangupa when praying, presenting and giving thanks and blessings to strengthen the spirit of someone in order to avoid danger, disaster or disturbance by the evil spirits; manulangi or sulang-sulang, whichmeans giving some well prepared food to someone in order to make their spirit become more alive and happy; pamasumasuparbagason for wedding customs. In these traditional events there will be many proverbs that convey messages to strengthen and to motivate the people in the ceremony.
A Batak Toba wedding ceremony consists of stages, starting frommarhusip to introduce the woman's and the man's families; marpudunsaut or martumpol to negotiate the dowry with the woman's family and to discuss the things that must be prepared for the traditional wedding ceremonyand lastly pamasumasuanparbagason the wedding ceremony. These wedding steps are usually followed by Christian Batak.

Marhusip is the first stage whereby the families of prospective bride and bridegroom are introduced to each other. At this time, they meet at the woman's family house. This is a very important meeting to help both families adapt, as they meet in a convenient manner and a friendly situation. Because the two families hope to be one big family through the marriage, the situation must be comfortable and friendly. For this ceremony, the family and relatives of the man come to the woman's family to introduce themselves and the place they come from, and finally ask permission for the man to be engaged to the woman. After that they discuss the times and the dates of the martumpol and the pamasumasuanparbagason. But before starting this conversation they always begin by having lunch. Finally they agree to the engagement to continue the next stage of martuppol with prayer so that the party and the next meeting will go smoothly.

Martumpol follows marhusip, before finishing with pamasumasuanparbagason, which is always held in a church. This is when the two extended families of the woman and the man announce in church that their families would like to celebrate holy matrimony in the near future. Usually the church they choose is the woman's family's church. At this time, they invite not only both families but also neighbors, relatives, parishioners and others. To start martumpol, they have a church service and then the date of their impending marriage is recorded by the church administration. This record is used to announce the marriage to the church community and parish. It will be announced twice in two consecutive weeks in order to avoid any mistake or problem for both the bride and bridegroom.

After the church service, the party continues with the families' relatives and church representatives having lunch together on the church premises. And finally the conversation turns to discussing the dowry, the place, the date and details of the wedding program, related to the Batak culture, such as the exchange of ulos, the meat, usually beef or pork, and jambar, etc. The bride's family usually manages the pamasumasuanparbagasan and the event is closed with prayers and by saying ingot ingotwhich means please remember three times.

The final step of the marriage process is pamasumasuanparbagason, which takes a long time to finish, from morning to afternoon and even into the evening. What makes this process so long is that it includes marsibuhabuhai(the groom and his family picking up the bride from her house, accompanied by a walking music band). After having breakfast together at the groom's house, both families move on to the church for the church service, where the bride and bridegroom are blessed by the Protestant

Volume 6 Issue 12, December 2017

www.ijsr.net

Licensed Under Creative Commons Attribution CC BY 


\section{International Journal of Science and Research (IJSR) \\ ISSN (Online): 2319-7064}

Index Copernicus Value (2016): 79.57 | Impact Factor (2015): 6.391

clergyman or pastor. Afterwards they have lunch together, presenting the dowry, giving ulos (as a symbol of power and energy), giving tuhor (some money taken from the dowry and given to the bridegroom's family relatives), distributing jambar (some meat, which has been cut in certain portions, is given to both families and invited guests), and dancing tor-tor to express their happiness. During the giving activities, proverbs are always recited to the families of the marriage party as expressions of happiness and blessings, and praying to Almighty God that the two families will have eternal happiness, health and long lives. And finally, the party concludes by praying together in order to receive God's blessings.

\section{Proverbs for a Batak Toba Wedding}

In Batak culture, there are proverbs for many kinds of traditional customs. Some marriage proverbs are used differently according to the stage of the party. Examples can be seen below, such as:

\section{A. UmpasaManjaloTintinMarankup (Proverbs for a young man and woman when exchanging their gold engagement rings)}

- Bulungnamartampuk, bulungnisamarlasuna,

Nungahujalohamitintinmarangkup, Dohonon ma hatapasupasuna.

Picked leaves, leaves of poisonous tuber crops,

We have known witnessed a legal marriage so we will give words of blessing.

- Sai tong doilubangnangpedihukkupirere

Sai tong doiboruniTulang, manangboruniisepeidialapbere

It is a hole of ring of gold

It is true, she is uncle's daughter or other's, is nephew's couple

- Amak do rere, dakka do duppang

Anak do bere, amang do Tulang

A woven mat can be broken; a twig is not a branch

A son-in-law is a nephew, a father-in-law is an uncle.

- Asing do hutaHullang, asing muse do GunungTua

Asing do molotulang, asing muse do mologabe dung simatua.

It's different in the Hullang region; it's different in the GunungTua region.

It's different to be an uncle; it's different to be a father-inlaw.

B. Umpasatunabarumarbagas (Proverbs for a newly married couple)

- Dakkaniarirang, peak di tongaonan,

Badan mu nasojadisirang, tondi mu marsigomgoman.

The branch of a palm tree lies in the middle of the marketplace.
Your bodies will not be separated, your souls will bind.

- Giring-giring ma tugostagosta, tu boras nisikkuru

Saitibu ma hamumangiring-ngiring, huhutmangompaompaanakdohotboru

A bell is ringing, grain is from the barley grass. become one soon, have a son and a daughter.

- RimburniPakkatturimburniHotang

Saitudiapehamumangalakka, saitusimahamudapotpansamotan

The end of the Pakkat region is the end of the rattan.

Wherever you step, there you live.

- Dekkeni sale sale, dekkenisimamora

Tambaninagabe, saitibu ma hamumamora

Dried fish belong to the rich.

Have many and be rich.

- Sahatsahatnisolu, sahat ma tulabuan

Sahat ma hamulelengmangolu, jalasai di donganiTuhan

The boat arrives in port.

Live long and be with God.

C. UmpasaMangampu (Proverbs expressing gratitude to invited guests)

- SonggopsiRuba-rubatudakkanihapadan,

Angkapasu-pasunanilehonmuna, Saidijangkontondi ma dohotbadan

Asmall bird stands on a small twig.

The words of blessing you give, so be it with your body and soul.

- Mardakkajabi-jabi, marbulungiasiTulan

Angkapasu-pasunapinasahatmuna, SaisudemaidipasautTuhan

The branch of the banyan tree has leaves.

The words of blessing you give, may God grant them.

- Turtuninnaanduhur, tioninnalote,

Angka pas-pasupinasahatmuna, saiunangmuba, unangmose

The voice of a cuckoo bird is the voice of a quail.

The words of blessing you receive cannot be ignored

- Habangpidong, paihut-ihutbulan,

Saluhutangkanatapangido, saitibu ma dipasautTuhan

A bird flies to the moon.

All we ask is, that God will grant your request soon.

D. Umpasa Na Asing (Various Proverbs)

- Emenisimbolonparasarannisiborok

Saihoras-horas ma hita on laoDebata ma namarorot

Volume 6 Issue 12, December 2017

www.ijsr.net

Licensed Under Creative Commons Attribution CC BY 


\section{International Journal of Science and Research (IJSR) \\ ISSN (Online): 2319-7064}

Index Copernicus Value (2016): 79.57 | Impact Factor (2015): 6.391

TheSimbolons' paddy field is the place of frogs.

So all of us will be healthy in God's care.

- Napurantano-tano ranging marsiranggongan

Badan ta I padaodao, tondita i marsigomgoman

Ground limestone spreads around.

We live away from each other, but our souls are united.

\section{- AekGodangtuaeklaut}

Dos nirohasibaennasaut

River water flows to the sea.

Harmony brings agreement.

For more complete Batakproverbs, please go to this site: http://www.doocu.com/pdf/view/22415

\section{Theoretical Basis of the Interpretation of Proverbs}

Semantics is language study related to translation study, a branch of language science that emphasizes the meaning of words. According to the definition of semantics taken from Richmond H. Thomson, 1996, Semantics is the study of meaning of linguistic expressions. And According to the definition of Encyclopedia Americana Volume 24, 1986 "semantics is the study of meanings. The term is derived from the Greek "semaintein (to signify or mean). It is concerned with the relationships between words or other symbols and the objects or concepts to which they refer, as well as with the history of meanings and the changes they undergo. As an empirical study of word meanings in existing language, semantics is a branch of linguistics........"

Semantic studies, which analyze the meanings of proverbs, apply the study of the meaning component to represent the individual meaning of the words, and to show how the meanings of words interrelate with each other. In semantics, the type of lexical relation behind the proverbs can be analyzed, related to the word choice, situation, purpose and target.

The study of translation theory includes the history, culture, and the progression of a language, such as English language, which commonly refers to the culture of Classical Greece and Rome, similar to Bahasa Indonesia vocabulary adapted from Sanskrit. Because of the cultural background, the translation method recommended by many experts is namely indirect translation. In a translation activity, it is better for the translator to get the meaning from the content of the entire text. Having understood the meaning, the translator can then start work

Indirect translation involves transferring the meaning from the source language into the target language. In the case of transferring the meaning, the important aspect that needs to be noted is the accuracy of meaning. This is not achieved by translating word-to-word meanings but by an indirect translation method, which is called transfer of meaning from the resource language to a target language. In other words, the translation must be able to transfer the meaning from the source language into the target language without deviation in the meaning. In English that methodology is called 'transference'.

In indirect translations or transfer of meaning, the main tool is sentences to express natural feelings, thoughts or ideas, which are acquired from direct or written text. The translator reads or listens to the sentences from the source text and then translates them into the target language in different syntax. Because of that, the sentence comes first in this translation work.

Some linguists, such as Eugene A. Nida and Charles R. Taber in their book "The Theory and Practice of Translation", among others, who wrote applied theories as a reference in translation work, argue that in a translation, the recipient is preferred. Because of that, the reaction or motion of reply of the recipient must be considered. Motion of reply, will later be compared to the same recipient to check whether the same message is being delivered in the source language. J.C. Catford in his book, "A Linguistic Theory of Translation", described the importance of knowing various elements of language, such the classification levels rules and phonology. The language classification exists because it relates to the situation of the society where the language is used.

Prof Dr. E. Sadtono emphasizes the domination of two languages, such as the source and the target language in his book, "Translation Guidelines". The meaning of the domination of a language is the ability to read, write and speak. By dominating languages, the translator is able to transfer information from a source language to a target language. Mildred Larson (1989: 3) states that translation work means "study lexicon, grammatical structure, communication situation, and cultural context of the language resource text".

According to Learner's Dictionary, Interpretation focuses on the act or result of explaining or interpreting something: the way something is explained or understood. People give them the understanding of interpretative such as social action. All of these interpretative theories focus on the way to define social situations and the effect of the definition towards the next action and interaction.

Semantics and translation theory is the science, which is applied to analyze language interpretation. In the study of semantics a proverb is a group of words or sentences containing a meaningful message or a deep meaning, but not a simple lexical meaning. To analyze the meaning of a proverb, we need to know the language context in order to know the accurate meaning. This statement shows that the understanding step starts from translation to get the lexical meaning and is then interpreted by using semantics in order to reach the meaning and the motivations inside the sentence and proverb, without losing the language context.

In Webster's Dictionary, “interpretation(noun) means:

1.the act or process of interpreting or explaining, elucidation

Volume 6 Issue 12, December 2017 


\title{
International Journal of Science and Research (IJSR) \\ ISSN (Online): 2319-7064
}

Index Copernicus Value (2016): 79.57 | Impact Factor (2015): 6.391

2.the result of interpreting; an explanation

3. a particular view of an artistic work, esp. as expressed by stylistic individuality in its performance

Beside that, translation (noun) means:

1.something that is or has been translated, esp. a written text 2.the act of translating or the state of being translated

\section{Analysis of Proverbs}

The purpose of the implementation of this interpretation is to understand the meaning of the words, phrases, sentences, and proverbs deeply. Supporting to the above statement that translation theory is appropriate to support the interpretation meaning. What is written translated and interpreted. The example can be seen in the Batak Toba traditional wedding. In this case the writer was concerned to analyze the messages within the proverbs (in Batak it is called 'umpasa' and 'hatapasupasu) and sentences conveyed at that event. Proverbs frequently conveyed at a traditional Batak wedding include:

\section{A. UmpasaManjaloTintinMarankup (Proverbs for a newly married couple after being blessed by the Protestant clergyman or pastor)}

- Bulungnamartampuk, bulungnisamarlasuna,

Nungahujalohamitintinmarangkup, Dohonon ma hatapasupasuna.

Picked leaves, leaves of poisonous tuber crops,

We have witnessed a legal marriage so we will give words of blessing.

\section{Interpretation:}

It states that something, which has been stated must be accepted. It cannot be ignored. Just like the leaves, which are cut from their stalk, they cannot be united anymore, and so it is with holy marriage. Because of that, the marriage must be supported by giving words of blessing and by praying to God.

- Sai tong doilubangnangpedihukkupirere

Sai tong doiboruniTulang, manangboruniisepeidialapbere

It is a hole of ring of gold

It is true, she is uncle's daughter or other's, is nephew's couple

\section{Interpretation:}

Marriage is just like a ring. It is round and has a hole, and it is firm. That is a relationship, which is round. It cannot be separated, because it is united in one round line. That is like a family relationship, which is formed through the bride's marriage to the bridegroom. She will be the daughter of an uncle, although she is not a blood relative, if a nephew marries her.

- Amak do rere, dakka do duppang

Anak do bere, amang do Tulang

An old mat is woven; a twig is not a branch
A son-in-law is a nephew; a father-in-law is an uncle. Interpretation:

This proverb states that a woven mat, is still useful although it is old. And similarly a twig, which is small and attached to the branch of a tree, becomes one body. It is the same as a son-in-law becomes a nephew of the father's wife in a family, and the father-in-law is an uncle in another relationship. Then both become part of the one big family.

- Asing do hutaHullang, asing muse do GunungTua Asing do molotulang, asing muse do mologabe dung simatua.

It's different in the Hullang region; it's different in the GunungTua region.

It's different to be an uncle; it's different to be a father-inlaw.

\section{Interpretation:}

It just like the two places are different from each other. So the uncle and the father-in-law are different from each other. This means that the son-in-law must understand the positions of both the uncle and the father-in-law.

\section{B. Umpasatunabarumarbagas (Proverbs for a newly married couple)}

- Dakkaniarirang, peak di tongaonan,

Badan ти nasojadisirang, tondi mu marsigomgoman.

The branch of a palm tree lies in the middle of the marketplace.

Your bodies will not be separated, your souls will bind.

\section{Interpretation:}

This proverb describes the analogy of a branch of a palm tree, whose condition is observed by many people. Is the branch good and worth selling? It could be said that on analysis the above proverb is motivational and has a strong moral message for the couple. The purpose of this proverb is to strengthen the marriage relationship, comparing the body and soul of the bride and bridegroom, which cannot come apart, as a marriage is not easily separated or broken. The positive and the negative side of marriage will be noticed and seen by many people. This message is strongly motivational for an individual and for society in general.

\section{- Giring-giring ma tugostagosta, tu boras nisikkuru Saitibu ma hamumangiring-ngiring, huhutmangompa- ompaanakdohotboru}

A bell is ringing, grain is from the paddy plant. become one soon, have a son and a daughter.

\section{Interpretation:}

Just like plants produce grains and barley, a couple has sons and daughters. Do not wait for long as a bell is ringing for you to get started.

\section{- RimburniPakkatturimburniHotang \\ Saitudiapehamumangalakka, saitusimahamudapotpansamotan}

\author{
Volume 6 Issue 12, December 2017 \\ www.ijsr.net \\ Licensed Under Creative Commons Attribution CC BY
}




\section{International Journal of Science and Research (IJSR) \\ ISSN (Online): 2319-7064}

Index Copernicus Value (2016): 79.57 | Impact Factor (2015): 6.391

The end of the Pakkat region is the end of the rattan.

Wherever you step, there is where you live.

\section{Interpretation:}

Just like rattan, which spreads and lives everywhere, so too can the newly married couple live anywhere.

- Dekkeni sale sale, dekkenisimamora

Tambaninagabe, saitibu ma hamumamora

Dried fish belong to the rich.

have many and be rich.

\section{Interpretation:}

Just like a rich person who has a lot of food to eat, have many children and be rich.

- Sahatsahatnisolu, sahat ma tulabuan

Sahat ma hamulelengmangolu, jalasai di donganiTuhan

The boat arrives in port.

Live long and be with God.

\section{Interpretation:}

Just like a boat always comes back to port, so a married couple must live according to God's wishes.

C. UmpasaMangampu (Proverbs for responding to and expressing gratitude to the guests for coming, and for their words of blessing and congratulations)

- SonggopsiRuba-rubatudakkanihapadan,

Angkapasu-pasunanilehonmuna, Saidijangkontondi ma dohotbadan

\section{Interpretation:}

It is an expression of gratitude to say that all prayers given and all blessings received will be one in our body and soul.

\section{- Mardakkajabi-jabi, marbulungiasiTulan \\ Angkapasu-pasunapinasahatmuna, \\ SaisudemaidipasautTuhan}

The branch of the banyan tree has leaves.

The words of blessing you give, may God grant them.

\section{Interpretation:}

It is an expression of the idea, that all prayers given and all blessings received will be granted by God.

\section{- Turtuninnaanduhur, tioninnalote,}

Angkapasu-pasupinasahatmuna, saiunangmuba, unangmose The voice of a cuckoo bird is the voice of a quail.

The words of blessing you receive cannot be ignored.

\section{Interpretation:}

It means that a blessing which has been received, one cannot ignore a blessing
Saluhutangkanatapangido, saitibu ma dipasautTuhan

A bird flies to the moon.

All we ask is, that God will grant it soon.

\section{Interpretation:}

Just like a bird, which flies to places it wants to be, so humans can go everywhere they want to fulfill their desires. God can make our prayers come true.

\section{Umpasa Na Asing (Various Proverbs)}

- Emenisimbolonparasarannisiborok

Saihoras-horas ma hita on laoDebata ma namarorot

TheSimbolons' paddy field is the place of frogs.

So all of us will be healthy in God's care.

\section{Interpretation:}

We expect God to care for us every day.

- Napurantano-tano ranging marsiranggongan

Badan ta I padaodao, tondita i marsigomgoman

Ground limestone spreads around.

We live away from each other, but our souls are united.

\section{Interpretation:}

Absence makes the heart grow fonder

- AekGodangtuaeklaut

Dos nirohasibaennasaut

River water flows to the sea.

Harmony brings agreement.

\section{Interpretation:}

Just like water from the river flows into the sea, whether it is fresh or salty the water it can be together in one place, in the sea. It is the same for humans. Although humans are different, if they live in harmony, they can be as one, like the water in the sea.

\section{Conclusion}

From the analyses of this study it can be seen that Batak proverbs have been created by using analogies to nature and the environment. The proverbs are different in purpose, but they all serve to educate and motivate Batak people to live in harmony and have good manners. The proverbs are presented in a special way, using poetic words and containing two lines of text with different composition. The first line is a kind of analogy that can be described from words about animals, plants, trees, places of which is can be a character. And the second line contains a message of education and the motivation to live a good life, with good manners and character.

\section{References}

[1] Bangkaru, Mahmud, 2001, Handbook to North Sumatra, Banda Aceh, PenerbitBalohanHaloban

[2] Bloomfield, Leonard, 1993, Language. New York: George Allen \&Unwin Ltd

- Habangpidong, paihut-ihutbulan, 


\section{International Journal of Science and Research (IJSR) \\ ISSN (Online): 2319-7064}

Index Copernicus Value (2016): 79.57 | Impact Factor (2015): 6.391

[3] Catford, J.C. 1967, A Linguistic Theory of Translation, Oxford University Press, London

[4] Encyclopedia Americana Vol. 24, 1986, Semantics

[5] Larson, Mildred. 1989, PenerjemahBerdasarMakna: PedomanuntukPemadananAntarbahasa .

(DiterjemahkanolehKencanaTaniran) Jakarta: Arcan

[6] Nida and Taber, Eugene A. and Charles R.1969, The Theory and Practice of Translation, E.J. Brill, Leiden

[7] Ridwan, T.A.R. 2002.BahasadanKebahasaan. Medan: USU Press

[8] Ridwan, T.A.R. 2003.BahasadanLinguistik. Medan: USU Press.

[9] Sapir, Edward, 1949, Language, Language. New York: Harcout, Brace \& World Inc

[10] Sadtono, E. 1985, PedomanPenerjemahan, PusatPembinaandanPengembanganBahasa, Jakarta

[11] Siahaan, 1982, AdatDalihanNatolu PrinsipdanPelaksanaannya, Medan: Prima Anugerah

[12] Saeed, John, 1977. Semantics, United Artist Corporation.

[13] Vergouwen, J.C. Het rechtsleven der Toba-Bataks (Den Haag, 1933)

[14] http://aimanmuhsintahir.wordpress.com/2010/06/06/sedi kit-tentang-teori-interpretasi

[15] http://www.thefreedictionary.com/interpretation

[16] http://www.doocu.com/pdf/view/22415

[17] http://www.omniglot.com/writing/batak.htm .

[18] http://www.learnersdictionary.com/definition/interpretat ion

\section{Author Profile}

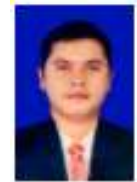

Author is a lecturer in Medan Tourism Academy, North Sumatera Indonesia. He was graduated from Post Graduate School of Linguistics Study, North Sumatera University, Indonesia, Year 2004. 